\title{
Learning conversions in science: the case of vocational students in the UK
}

\author{
Anne Butterfield, Rosamund Sutherland and Susan Molyneux-Hodgson \\ Graduate School of Education, University of Bristol \\ email:s.molyneux@bristol.ac.uk
}

The paper describes two aspects of a research project that focused on vocational science students. The paper begins with a general description of vocational science in the UK, to put the work in context. It then outlines an analysis of the ways in which these students approach problems involving converting between units of measurement. Finally the development and evaluation of computer-based activities designed to support students in learning about unit conversion are described.

\section{Introduction and background}

Within this paper we discuss some of the results of a research project in which we analysed the ways in which vocational science students approached problems involving converting between units of measurement, in the context of science. The project also involved the development and evaluation of computer-based activities written to support pupils in learning about conversions. We started from the premise that learning to convert between units of measurement is critical to a learners' development in the realm of science and that having access to a general method would support students' efficiency in converting. Our focus on the role of a general rule for converting arose out of a detailed observational study of students working through their science courses (Molyneux and Sutherland, 1996). As a backdrop to our research, we will first discuss the vocational education context in the UK.

Vocational education in the UK has undergone quite substantial changes since the beginning of the 1990s. One product has been the creation of school- and college-based vocational qualifications (GNVQs) which are in some way equivalent to the more traditional academic courses, in recognition of the different purposes of academic and vocational learning (Dearing, 1996). The model for the new qualification was influenced by 
studies of the German, Austrian and Swiss education systems in which the academic and vocational tracks are separate but where the vocational track has high status due, partially, to its substantial content of general education (Hodgson and Spours, 1997).

It was hoped that the broad vocational route afforded by the new GNVQs would attract some students away from the academic pathway in order to increase participation and achievement at the vocational level and increase the numbers remaining in education. Historically there have always been vocational awards in the UK but these have never been attractive to the vast majority of post-16 students and have usually been taught in the post16 further education colleges and not in schools. The new school- and college-based vocational qualifications, targeted at the 16-19 age group and equivalent to the academic A levels, are called Advanced General National Vocational Qualifications. Today, the number of 16-year-old students participating in Advanced GNVQs is greater than that in other advanced vocational qualifications by three to one. However these students have not been attracted away from the academic A levels but from the other existing vocational courses such as the Business and Technical Education (BTEC) and City and Guilds awards (Robinson, 1996; Spours, 1997).

The expansion of GNVQs at the expense of the more traditional vocational awards has not been matched by student achievement (Spours, 1997). The GNVQ successful completion rate of 55 per cent is lower than that of both the long-standing vocational and academic awards where, for example, a successful completion rate of over 70 per cent is typical for BTEC National awards and A-levels (Robinson, 1996; Spours, 1997).

GNVQs are available in fifteen subject areas including Leisure and Tourism, Business Studies and Science. They are a broad vocational qualification requiring students at the Advanced level to complete eight mandatory and four optional units of the specialist subject, and three 'key skills' units of Communication, Application of Number and Information Technology. Successful completion of an Advanced GNVQ, which takes two years, is equivalent to two passes at $A$ level and is a recognized qualification for entry into university. Foundation and Intermediate GNVQs are also available. These require the completion of fewer mandatory and optional units but still contain the compulsory three key skills units.

Key skills have a fundamental role in the qualification but are not usually taught as separate subjects; they are meant to be 'embedded' in vocational situations to appear more relevant to the learner (Spours, 1997). Studies of the delivery of key skills in practice, however, reveal a great deal of variation in the approach taken by schools and colleges, with some favouring embedding but others adopting stand-alone strategies (FEU/IOE/Nuffield, 1994). The embedded approach has been criticized by the UK schools' inspectorate (OFSTED) for not allowing the systematic development of mathematical and language skills and thus providing very few examples of good work (OFSTED, 1994). This approach also contrasts with the stand-alone delivery practices of European vocational systems, which provide greater levels of attainment in key skills areas (Green and Steedman, 1993; Wolf, 1995).

A further distinguishing characteristic of the new vocational qualification is its emphasis on independent learning through portfolio compilation. Students gain the award through producing a portfolio of evidence which demonstrates they have fulfilled the performance 
criteria laid out for all of the units. The need for the students to plan their own work and search for relevant information has led to a collaborative and active style of learning recognized in inspection reports as the greatest strength of the new award (FEFC,1994; OFSTED, 1994). It is, however, the failure of students to finish their portfolio that is the major factor in the poor completion rates of GNVQ programmes (Spours, 1997). Students find themselves embroiled in matching the contents of their portfolio with the complex demands of the many performance criteria required for each unit. Spours (1997) suggests that this concentration on the 'administration' of their learning has adversely affected fundamental skill development and theoretical understanding amongst GNVQ students and has contributed to the halting of GNVQ provision in some further education colleges in favour of the traditional BTEC vocational awards.

\section{The research project: introduction}

Two of the defining characteristics of the new vocational qualifications, namely the inclusion of embedded key skills and the emphasis on independent and active learning, are seen as critical in the provision of a broad education leading either to further training within employment or to further and higher education (NCVQ, 1995). The interaction of these two features of practice is also one of the major concerns of our research project. Working within the context of the Advanced GNVQ Science course we have been prompted to ask whether an educational model which requires students to take responsibility for their own learning and which embeds key skills in a vocational context is likely to equip students with the key skills necessary for further training, education or work. We shall attempt to answer this question in this paper by describing our research project and the findings related to students' approaches to converting between units of measurement in science. The aims of our work were:

- to characterize the mathematical competencies of vocational science students on entry to the GNVQ (Advanced) Science course;

- to investigate the advantages and disadvantages of the GNVQ approach to mathematics;

- to investigate the role of computer-based activities in the development of mathematical competencies of vocational science students.

We had anticipated that the mathematical background of GNVQ students would be weak and we conjectured that the use of computer-based activities might support students in developing some of the mathematical skills essential to science learning.

\section{Methods}

The methodology incorporated several strands. The mathematical competencies and practices of twenty-one Advanced GNVQ Science students from two further education colleges were first characterized through a diagnostic test. (This test has also been administered to a further sixty-seven vocational science students in five other colleges in England.) We carried out extensive classroom observations during the vocational course and conducted a series of interviews with students on observations of science, such as the mathematical aspects of their assignments. The students from our two participating 
colleges then engaged in a set of computer (spreadsheet)-based activities, designed to teach aspects of mathematics for science. Follow-up interviews and a repeat of the diagnostic test were also conducted after the students had completed the spreadsheet work. The mathematical areas investigated were: 'Conversions' (converting between units of measurement) and 'Graphs' (fitting data to straight line graphs). In this paper we focus on our findings from the 'Conversions' study.

Conversions are an integral part of much scientific practice, for example to allow for ease of data processing, to enable comparison and standardization and to support the understanding of physical quantities and processes (Molyneux and Sutherland, 1996). It is therefore crucial for science students to become competent in converting between units. For this reason, the area of 'Conversions' was selected as a research topic. Analysis of the initial diagnostic test administered to seventy-nine students showed that:

- vocational science students used a range of informal methods to solve conversion problems;

- the majority of students were successful at converting between 'simple' metric quantities such as from grams to kilograms and from millilitres to litres (and vice versa);

- no student could convert between centimetres squared and metres squared;

- the majority of students were unsuccessful at converting quantities expressed in standard form or in units with indices;

- the diversity and informality of students converting methods on simple problems (e.g. $\mathrm{cm} \rightarrow \mathrm{m}$ ) meant it was unlikely they would develop more generalized understandings of converting which may have supported them in complex converting problems (such as $\mathrm{cm}^{2} \rightarrow \mathrm{m}^{2}$ ).

These findings influenced the design of the 'Conversions' spreadsheet activities, which aimed to support students in learning to convert between units of measurement and to construct a formal general conversion relationship. Students worked through three 'teaching scenarios' in consecutive weeks, with each scenario lasting one and a half hours. In Scenario 1 the students worked in pairs to solve four conversion tasks presented as spreadsheet activities. The activities were designed to develop spreadsheet skills as well as offer a tool towards development of more formal converting strategies. Scenario 2 was less prescriptive and asked the students to use the spreadsheet to support the determination of the density of different cubes of material; they were provided with materials, rulers and weighing scales and had to present density calculations in the units of $\mathrm{kgm}^{-3}$ although they had measured mass in grams and length in centimetres. Scenario 3 consisted of three pencil-and-paper activities designed to develop further students' understanding of conversions.

As the students worked through the spreadsheet activities of Scenarios 1 and 2 and the paper-based exercises of Scenario 3, we recorded their conversations and problem-solving strategies by video-recording one pair of students, audio-recording a second pair of students and taking detailed observation notes of a third pair of students. The spreadsheet work of all the students was also saved to disk and all written responses on the students' worksheets gathered in at the end of each scenario. Whilst one or two members of the 
research team acted as researchers one member took on the role of teacher, being available to respond to students' requests for help and to intervene when they deemed appropriate.

This paper describes student responses to the last of four spreadsheet activities presented in Scenario 1. This task was designed to present students with one method of working which would provide them with information for use in the solution to a second part of the task. This corresponds to Vygotsky's 'functional method of double stimulation' in which an individual is faced with a task beyond his or her present capabilities and then given additional ('auxiliary') stimuli to incorporate into their problem-solving (Vygotsky, 1978). A micro-analysis of two students, Heidi and Ruth, at work is described and discussed, followed by a summary and discussion of the range of strategies used by all students during this activity. Finally, we attempt to draw inferences from this analysis with regard to the role of teacher and computer in the students' acquisition of appropriate formal rules.

\section{Case study: Heidi and Ruth converting between simple metric units}

\section{Introduction}

In the following sections we present the case of two students solving a conversion problem using a spreadsheet. We describe their activity before discussing the implications of this on their learning.

MethodA. Find the cross-sectional areas of a collection of wires in $\mathrm{m}^{2}$. The diameters are shown below:

\begin{tabular}{l|l|l|l}
\hline diameter $(\mathrm{mm})$ & radius $(\mathrm{mm})$ & radius $(\mathrm{m})$ & x-sectional area $\left(\mathrm{m}^{2}\right)$ \\
\hline 0.27 & 0.135 & & \\
\hline 1.106 & & & \\
\hline $7 \mathrm{E}-2$ & & & \\
\hline $8.3 \mathrm{E}-1$ & & & \\
\hline
\end{tabular}

cross-sectional area of a wire $=\pi r^{2} \quad$ ' $r$ ' = radius of the wire

Method B. Another way of finding cross-sectional area is shown below for you to try:

\begin{tabular}{l|l|l|l}
\hline diameter $(\mathrm{mm})$ & radius $(\mathrm{mm})$ & x-sectional area $\left(\mathrm{mm}^{2}\right)$ & x-sectional area $\left(\mathrm{m}^{2}\right)$ \\
\hline 0.27 & 0.135 & & \\
\hline 1.106 & & & \\
\hline $7 \mathrm{E}-2$ & & & \\
\hline $8.3 \mathrm{E}-1$ & & & \\
\hline 13.45 & & & \\
\hline
\end{tabular}

Figure 1:The spreadsheet task from Scenario 1 - presented on paper - designed to help students learn to convert from $\mathrm{mm}^{2}$ to $\mathrm{m}^{2}$. 
In the final question (Figure 1) from the spreadsheet activities of Scenario 1 students were presented with two different methods for calculating the cross-sectional area of a wire in $\mathrm{m}^{2}$. In method $\mathrm{A}$, for given diameter of wire (in $\mathrm{mm}$ ), students needed to divide by 2 (to give radius in $\mathrm{mm}$ ); convert from radius in $\mathrm{mm}$ to radius in metres $(\div 1000)$, then use this value to calculate the area of the wire $\left(\pi r^{2}\right)$. In method $B$, students first calculate area in $\mathrm{mm}^{2}$ and must then convert to $\mathrm{m}^{2}$. Comparing the cross-sectional areas obtained from the two methods was intended to provoke the students into realizing that to convert from $\mathrm{mm}^{2}$ to $\mathrm{m}^{2}$ requires a division of $1000^{2}$. We had assumed (from the analysis of the initial diagnostic test) that Method A would pose few problems but that to convert from $\mathrm{mm}^{2}$ to $\mathrm{m}^{2}$ in Method B would be difficult for the students. We predicted that students would divide by 1000 instead of $1000^{2}$ when converting from $\mathrm{mm}^{2}$ to $\mathrm{m}^{2}$ in Method $\mathrm{B}$ and that by comparing the results with those of Method A would work out that the conversion from $\mathrm{mm}^{2}$ to $\mathrm{m}^{2}$ required in Method $\mathrm{B}$ is a division of $1000^{2}$.

In terms of the Vygotskian idea of the zone of proximal development, the conversion from $\mathrm{mm}^{2}$ to $\mathrm{m}^{2}$ in the final step of Method B was the task we considered to be beyond the students' present capabilities. The expected correct values for 'cross-sectional area $\left(\mathrm{m}^{2}\right)$ ' in Method $\mathrm{A}$ were intended to provide the additional stimuli for students to solve the final conversion step in Method B. As we will describe however, this process was not so simple in practice.

\section{Heidi and Ruth's work, Method A}

Using the first method, Heidi and Ruth enter the five diameters correctly into column A of the spreadsheet. They next obtain a correct set of radii ( $\mathrm{mm}$ ) in column $B$ by entering the formulae $=A 2 / 2,=A 3 / 2$ etc. into cells B2 to B6 (Figure 2). When converting the radius of $0.135 \mathrm{~mm}$ into metres, in cell C2, Heidi and Ruth type in an incorrect formula of B2*1000 (instead of the correct B2/1000). That is, they convert from millimetres to metres by multiplying by 1000 instead of dividing by 1000 . When the incorrect value of 135 (rather than the correct value of 0.000135 ) appears in cell $\mathrm{C} 2$ as the radius (m), Ruth knows that something is wrong. Their spreadsheet at this point appears as shown in Figure 2.

\begin{tabular}{|l|l|l|l|}
\hline 1 & $\begin{array}{l}\text { A } \\
\text { diameter }(\mathrm{mm})\end{array}$ & $\begin{array}{l}\text { B } \\
\text { radius }(\mathrm{mm})\end{array}$ & $\begin{array}{l}\mathrm{C} \\
\text { radius }(\mathrm{m})\end{array}$ \\
\hline 2 & 0.27 & 0.135 & 135 \\
\hline 3 & 1.106 & 0.553 & \\
\hline 4 & $7.00 \mathrm{E}-02$ & 0.035 & \\
\hline 5 & $8.30 \mathrm{E}-01$ & 0.415 & \\
\hline 6 & 13.45 & 6.725 & \\
\hline
\end{tabular}

Figure 2: Ruth and Heidi's spreadsheet after correctly converting from diameter $(\mathrm{mm})$ to radius $(\mathrm{mm})$ but mistakenly converting the radius of $0.135 \mathrm{~mm}$ to a radius of $135 \mathrm{~m}$.

Ruth (R), sensing that the value of 135 is not correct, discusses with Heidi $(H)$ what they should do about this.

R: A hundred and thirty five metres? (Looking at the answer in cell C2).

$\mathrm{H}$ : You're out by a point, aren't you? 
Heidi's response reflects a view, uncovered during student interviews, that converting between metric units involves moving the decimal point backwards or forwards (but with no conviction about which way this should be).

R: How can it be a hundred and thirty five metres? Times by a thousand? [Looking at the formula $=\mathrm{B} 2 * 1000$ in the formula bar]. Nought point one three five millimetres by what?

Heidi then offers that perhaps it is times by a 100 instead of 1000 .

H: Yeah, it's times, times, it's times a hundred.

Heidi then works out the conversion on her calculator to help her think through the problem. The students often use the calculator in this way.

At this point the teacher/researcher intervenes:

Int: What were you checking on the calculator?

R: That! [Pointing at the 135 in cell C2]. 'Cos that ain't right.

Int: How do you know it's not right?

$\mathrm{R}$ : It can't be a hundred and thirty five metres from that.

[Pointing at 0.135 in cell B2].

No chance. No chance of that, I'll try a hundred.

Ruth is obviously convinced that their answer is wrong but her strategy for debugging is to change to a multiple of 100 instead of 1000 . When they carry out an incorrect conversion Ruth often knows if it is wrong, indicating some sense of appropriate values. At this stage, however, they both use a 'trial and error' technique to find the correct conversion. They do not have any other type of knowledge which will allow them to decide whether to 'multiply' or 'divide'. Ruth replaces the formula of B2*1000 in cell C2 with a new but still incorrect formula of $\mathrm{B} 2 * 100$. She has recognized 135 as being too large and has agreed with Heidi that the solution may be to multiply 0.135 by a hundred instead of by a thousand. The (still incorrect) answer of 13.5 appears in cell C2.

R: That works!

H: Yeah, we'll have that.

$\mathrm{R}$ : We can live with that.

Again we intervene:

Int: How do you know that's right?

R: 'Cos it looks right.

Int: Have you any way of checking?

$\mathrm{R}$ : Not on the computer, no.

Int: So you reckon that point one three five millimetres is thirteen point five metres? How big's thirteen point five metres?

R: Something's wrong here.

Int: Show me how big you think point one of a millimetre is.

$\mathrm{R}$ : Cor blimey. It's minuscule innit?

$\mathrm{H}$ : Yeah. Tinee!

This intervention has convinced Ruth that their answer is still incorrect and she then 
decides to try multiplying by 10 instead of 100 . Her strategy seems to be 'decide if a conversion is too big or too small then adjust accordingly by decreasing the factor', that is, 'to make it smaller, multiply by a smaller number'.

Ruth changes the spreadsheet formula in the formula bar from B2*100 to B2*10. When the still incorrect answer of 1.35 appears in cell $\mathrm{C} 2$ the conversation proceeds as follows:

R: That still doesn't seem right. Nought point one three five millimetres, would be ... what would it be, what would it be, what would it be, what would it be? [scratching her head in concentration]. It would beeee ... Ten millimetres to a centimetre so ... nought point one millimetre is less than one millimetre, so it would be minuscule to centimetres, so ...

H: Thirteen point five, cos you're moving the decimal point aren't you? That's [pointing with her pencil between the 3 and 5 of 0.135 in cell B2] tocentimetres and that [pointing with her pencil to the end of 0.135 in cell B2] would be to metres 'cos you're moving the decimal point aren't you? So it is thirteen point five.

Ruth is still convinced that their conversion is incorrect. It is important to note that both students are repeatedly, and thoughtfully, considering whether their answers are sensible or not.

R: It can't be. [Adamantly and correctly]

$\mathrm{H}$ : No, but we had a hundred and thirty five, didn't we?

R: Yeah, but thirteen point five isn't right, either. How can point one three five be thirteen point five? Think about it, yeh? [Starts to write down the workings at the side of the table (Figure 1) on the worksheet. Mumbles the workings out loud as she does this]. Ten millimetres equals one centimetre ... We're dealing with less than a millimetre...

H: Exactly.

Ruth continues to write and draw on the provided worksheet, using a form of 'unitary' method to work out the conversion, combined with a qualitative approach involving order of magnitude. Her completed drawing, which she uses as she talks through the problem, is shown in Figure 3.

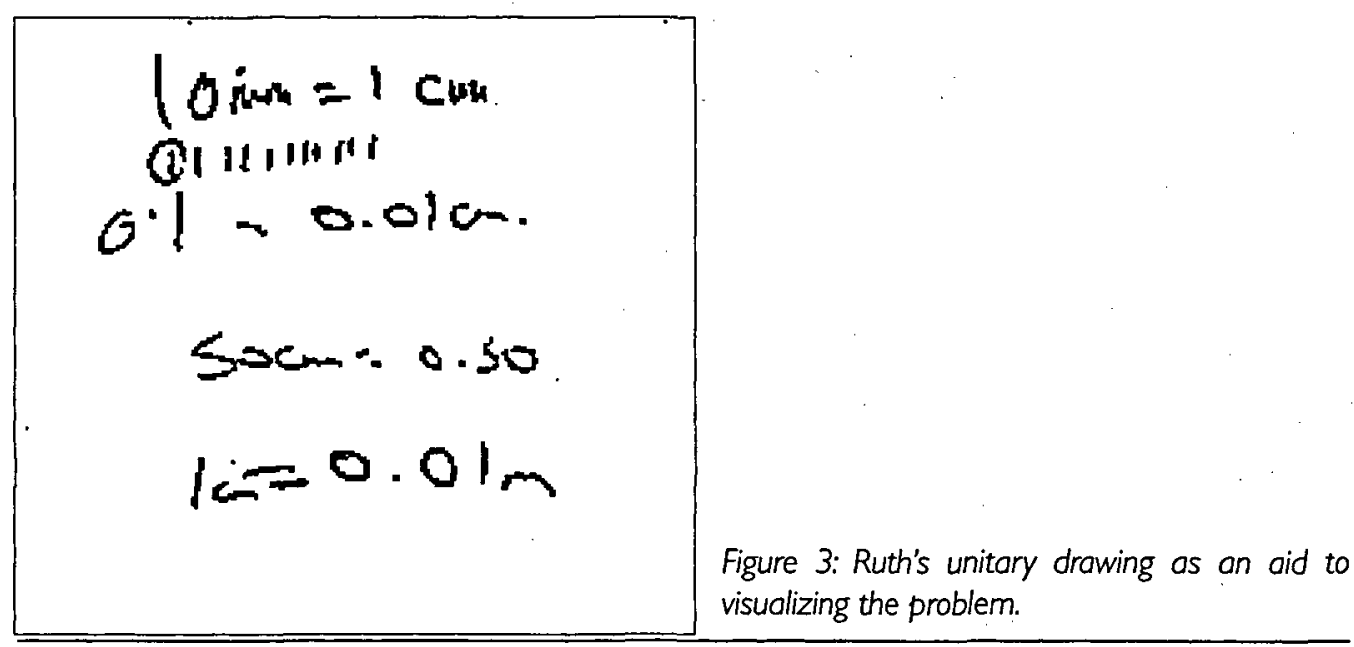


R: We're dealing with like nought point one ... I've got all the millimetres there ... [pointing at her drawing on the worksheet] . . . but we're dealing with like a single one o'those [pointing at a mm line on her drawing].

$\mathrm{H}$ : Yeh. That then is nought point nought one centimetres. Right? [pointing at the circled $\mathrm{mm}$ line on their drawing on the worksheet].

R: Yeh. So what would nought point nought one centimetres $(0.01 \mathrm{~cm})$ be in metres?

$\mathrm{H}$ : You move the decimal point ...

$\mathrm{R}$ : 'Cos fifty centimetres is nought point five ... ten centimetres is nought point one ... so one centimetre $(1 \mathrm{~cm})$ would be nought point . . . nought ... one of a metre $(0.01 \mathrm{~m})$ [writes this down on worksheet as she speaks through it].

$\mathrm{R}$ : And what we're dealing with is less than a centimetre. [Pause] So that's point nought one millimetres [pointing at the 0.135 in cell B2 but reading it out wrongly] ... we're dealing with less than a metre, so it can't be that can it? [pointing at the 1.35 in cell C2] So it can't be times, it'll have to be divide. Let's try that.

Ruth has convinced herself that it should be 'divide' instead of 'multiply' (correctly). Heidi's response is,

H: Divide it by what?

They begin to negotiate whether the dividing factor is 1000 or 100 .

R: Let's divide it by a hundred for a start ... see how we go.

This is done and the still incorrect answer of 0.00135 appears in cell C2. At this point they have not realized that the correct division is by 1000 and not by 100 . Through her discussion with Heidi, Ruth realizes that the division is by 1000 .

R: That works!

H: That'll do [chuckles].

$\mathrm{R}$ : What? [asking what $\mathrm{H}$ is laughing at] That looks more reasonable at least. But why have we divided it by a hundred?

$\mathrm{H}$ : Is it a hundred or a thousand now?

R: What have you done ... when you convert centimetres to metres ... you divide it by ...?

H: A hundred.

R: Yeh, so why have we got a hundred, it should be a thousand. I'll put the other nought in.

Ruth changes the formula in the formula bar from $\mathrm{B} 2 / 100$ to $\mathrm{B} 2 / 1000$. The correct answer of 0.000135 appears at last in cell $\mathrm{C} 2$.

R: Right. That works [coolly].

H: Yeh.

R: Right. Now we've solved the problem [both laugh].

The students then correctly copy down the formula in the remaining cells of column $\mathrm{C}$ of the spreadsheet to obtain a correct set of radii in metres (see column $\mathrm{C}$ in Figure 4 below). To begin converting the values in column $\mathrm{C}$ to the cross-sectional areas in $\mathrm{m} 2$ required in column $\mathrm{D}$, the students correctly enter the formula $=3.141^{*} \mathrm{C} 2{ }^{*} \mathrm{C} 2$ into cell $\mathrm{D} 2$ to obtain the correct answer of 5.72477E-08. They copy down the relative formula correctly from cell D2 into the remaining cells of column $\mathrm{D}$ to complete the exercise successfully. 


\begin{tabular}{|l|l|l|l|l|}
\hline 1 & $\begin{array}{l}\text { A } \\
\text { diameter }(\mathrm{mm})\end{array}$ & $\begin{array}{l}\text { B radius }(\mathrm{mm}) \\
\text { radius }(\mathrm{m})\end{array}$ & $\begin{array}{l}\mathrm{D} \\
\text { x-sectional area }\left(\mathrm{m}^{2}\right)\end{array}$ \\
\hline 2 & 0.27 & 0.135 & 0.000135 & $5.72447 \mathrm{E}-08$ \\
\hline 3 & 1.106 & 0.553 & 0.000553 & $9.60546 \mathrm{E}-07$ \\
\hline 4 & $7.00 \mathrm{E}-02$ & 0.035 & 0.000035 & $3.84773 \mathrm{E}-09$ \\
\hline 5 & $8.30 \mathrm{E}-01$ & 0.415 & 0.000415 & $5.40959 \mathrm{E}-07$ \\
\hline 6 & 13.45 & 6.725 & 0.006725 & 0.000142054 \\
\hline
\end{tabular}

Figure 4: Heidi and Ruth's successful completion of Method A.

\section{Heidi and Ruth's work, Method B}

Having correctly completed Method A, Heidi and Ruth continue with the second method (Method B) presented in the question. They begin by entering the diameter $(\mathrm{mm})$ values correctly in column A and then typing in the radii $(\mathrm{mm})$ in column B by copying the values obtained in Method A (Figure 5). The correct cross-sectional areas are also obtained in column $\mathrm{C}$ by using the basic formula of $\pi \mathrm{r}^{2}$ in cell $\mathrm{C} 10\left(=3.141^{*} \mathrm{~B} 10^{*} \mathrm{~B} 10\right)$ and changing it accordingly in cells $\mathrm{Cl1}$ to $\mathrm{C} 14$ (e.g. to $=3.141 * \mathrm{~B} 11^{*} \mathrm{~B} 11$ in cell $\mathrm{C} 11$ ).

In the final step, that of converting cross-sectional area $\left(\mathrm{mm}^{2}\right)$ in column $\mathrm{C}$ to crosssectional area $\left(\mathrm{m}^{2}\right)$ in column $\mathrm{D}$, Ruth and Heidi multiply the values in column C by 1000 instead of dividing them by $1000^{2}$. Their spreadsheet thus appears as shown in Figure 5.

\begin{tabular}{|l|l|l|l|l|}
\hline 9 & $\begin{array}{l}\text { A } \\
\text { diameter }(\mathrm{mm})\end{array}$ & $\begin{array}{l}\text { B } \\
\text { radius }(\mathrm{mm})\end{array}$ & $\begin{array}{l}\mathrm{C} \\
\text { x-sectional area }\left(\mathrm{mm}^{2}\right)\end{array}$ & $\begin{array}{l}\text { x } \\
\text { x-sectional area }\left(\mathrm{m}^{2}\right)\end{array}$ \\
\hline 10 & 0.27 & 0.135 & 0.057244725 & 57.244725 \\
\hline 11 & 1.106 & 0.553 & 0.960546069 & 960.546069 \\
\hline 12 & $7.00 \mathrm{E}-02$ & 0.035 & 0.003847725 & 3.847725 \\
\hline 13 & $8.30 \mathrm{E}-01$ & 0.415 & 0.540958725 & 540.958725 \\
\hline 14 & 13.45 & 6.725 & 142.0536881 & 142053.6881 \\
\hline
\end{tabular}

Figure 5: Heidi and Ruth's spreadsheet on completion of Method B.

The students realize that something is wrong when they notice the values in column $\mathrm{D}$ differ between the two methods (see column D, Figures 4 and 5). Recall that it was this event that had been anticipated by the researchers and designed to provide feedback to provoke further student action. They reformat the values in cells D10-D14 into standard form, as shown in Figure 6. 


\begin{tabular}{|l|l|}
\hline 9 & $\begin{array}{l}D \\
x \text {-sectional area }\left(\mathrm{m}^{2}\right)\end{array}$ \\
\hline 10 & $5.72 \mathrm{E}+01$ \\
\hline 11 & $9.61 \mathrm{E}+02$ \\
\hline 12 & $3.85 \mathrm{E}+00$ \\
\hline 13 & $5.41 \mathrm{E}+02$ \\
\hline 14 & $1.42 \mathrm{E}+05$ \\
\hline
\end{tabular}

Figure 6: Heidi and Ruth's values for $x$-sectional area $(\mathrm{m} 2)$ when reformatted into standard form.

R: We've got the same numbers but different powers [pointing at column D and noting the different values from the two methods].

$H$ : So they're not the same numbers are they?

$\mathrm{R}$ : No, but you've got the five seven two [pointing at D2] and the five seven two ' $e$ ' [pointing at D10]. And you've got the nine sixty [pointing at D3] and the nine six one [pointing at D11].

$\mathrm{H}$ : Yeh, but look... [pointing at the powers in cells D2-D6].

R: Yeh, that's what I mean ... they've got different powers. OK, I'm confused . . .'cos those are all the same [pointing to the values in columns A and B and referring to the fact that they are the same in both methods].

$\mathrm{H}$ : I know.

R: It must be that [pointing at cells C9-C14] . . 'cos we got it right now.

Heidi moves through cells $\mathrm{C10}-\mathrm{C11}-\mathrm{C12}-\mathrm{C} 13-\mathrm{C} 14$ and then D2-D3-D4-D5-D6 to check if the formulae in the formula bar are correct. At this point they appear to have exhausted their checking mechanisms and do not know how to resolve the problem of the different powers:

R: There! They're all all right. Let's just save it.

The spreadsheet session draws to a close and they do not resolve the discrepancy between the values for cross-sectional area $\left(\mathrm{m}^{2}\right)$ produced by the two methods.

\section{Discussion}

Heidi and Ruth encountered no problems in Method A when converting diameter into radius. Nor did they have any difficulty in using $\pi \mathrm{r}^{2}$ to obtain the cross-sectional area in $\mathrm{m}^{2}$ once they had finally obtained the radius in metres. It is therefore likely that these students are competent in using formulae such as $\pi r^{2}$ in calculations where the units required at the conclusion of the task are produced by the calculation itself. (In this case, substituting a radius already in metres into $\pi r^{2}$ automatically gives a cross-sectional area in the required units of $\mathrm{m}^{2}$ ). It is also clear that Heidi and Ruth knew and could apply the fact that radius is equal to half the diameter.

We conclude, however, judging from the time-consuming technique adopted by Heidi and Ruth in Method A to convert the radius from millimetres to metres, that they did not know, or could not remember in this context, that the general rule for converting from millimetres to metres is to divide by a thousand. Without recourse to this general rule, arriving at the correct conversion factor and its operation proved to be a great problem for 
them; to convert the radius of $0.135 \mathrm{~mm}$ to metres they tried five different operations, (1) $\times 1000$; (2) $\times 100$; (3) $\times 10$; (4) $\div 100$ and, finally, (5) $\div 1000$.

The case of Heidi and Ruth illustrates the inefficient strategies used by many of the science students who did not have access to a 'general' approach to everyday science conversion problems. Without a general rule to solve the problem, Heidi and Ruth tackled the conversion from millimetres to metres as if it were an investigation. Having no thorough knowledge of the correct conversion strategy they used a 'trial and refinement' process of successively reducing the conversion factor, relying on a qualitative sense of whether to accept it or not. The trial and refinment method is grossly inefficient when compared with the immediate use of a general rule. This case does illustrate however students' ability to draw upon their own resources in problem-solving when more formal resources are weakly understood or have never been learned. For example, Ruth created a visual image (see Figure 3) to support her work on the problem.

After the laborious construction of the correct method (dividing by a thousand) to convert from millimetres to metres in Method A, Heidi and Ruth did not embark on a similar process to derive the appropriate general rule for the conversion between $\mathrm{mm}^{2}$ and $\mathrm{m}^{2}$ in Method B. Instead of dividing by $1000^{2}$ as required, Heidi and Ruth multiplyied the crosssectional area $\left(\mathrm{mm}^{2}\right)$ by 1000 to obtain the cross-sectional area $\left(\mathrm{m}^{2}\right)$ (see Figure 5 ). The students noticed immediately that the set of values for the cross-sectional area $\left(\mathrm{m}^{2}\right)$ differed in Method B (Figure 5) from those of Method A (Figure 4). Knowing that they should have been the same, Heidi and Ruth reformatted the values in Method B into standard form (Figure 6), which, when compared with the results from Method A clearly show that Method B's results were too great (by a magnitude of $1 \times 10^{9}$ ). The students indicate from their conversation that they recognize a discrepancy in the 'powers' but are not able to 'unpack' the reason for this discrepancy. For these two students the nature of the spreadsheet-based task did not provide sufficient resources for them to 'work out' that converting from $\mathrm{mm}^{2}$ to $\mathrm{m}^{2}$ requires a division of $1000^{2}$. The correct values in Method A did not provoke them to recognize the general rule for converting between $\mathrm{mm}^{2}$ and $\mathrm{m}^{2}$, almost certainly because the intended confrontational situation had become too complex due to the students' error of multiplying the cross-sectional area $\left(\mathrm{mm}^{2}\right)$ by 1000 .

The repeated use of multiplication to convert from millimetres to metres is probably based on a knowledge that as metres are 'bigger' than millimetres, the correct operation is to multiply in order to obtain a 'bigger'value.

The intervention from the teacher/researcher when Heidi and Ruth were working on Method A seems to have been critical in provoking them to reconsider their work and without this intervention they may not have successfully completed this part of the problem. With respect to Method B it is also possible that an appropriate intervention would have helped them to move forward.

\section{The range of strategies used by the whole group}

Through analysis of the whole cohorts' spreadsheet work, we have been able to distil student responses to the conversion task into three distinct categories, 1, 2 and 3. Data from 18 students ( 9 pairs) that we observed in the two participating colleges, 6 pairs from College $\mathrm{A}$ and 3 pairs from College $\mathrm{B}$, has been drawn upon to distinguish those cases in which the intended problem-solving scenario was accessed by students successfully or not! 


\section{Response Category I, problem-solving scenario established}

Students in this category completed correctly the three conversion steps in Method A to obtain the correct value for ' $x$-sectional area $\left(\mathrm{m}^{2}\right)$ ' in the final column. They also completed correctly the first two conversion steps in Method B but made an error in the final step when converting from ' $x$-sectional area $\left(\mathrm{mm}^{2}\right)$ ' to ' $\mathrm{x}$-sectional area $\left(\mathrm{m}^{2}\right)$ '. The situation we had intended to provoke was therefore established, as the students were left to resolve the difference between two sets of results for ' $x$-sectional area $\left(\mathrm{m}^{2}\right)^{2}$ ', one correct (Method A) and one incorrect (Method B). The values for ' $x$-sectional area $\left(\mathrm{m}^{2}\right)$ ' should, of course, have been the same in both methods.

Five pairs (ten students) fell into this category. Instead of dividing correctly by $1000^{2}$ in the final step of Method B, four pairs converted area in $\mathrm{mm}^{2}$ into $\mathrm{m}^{2}$ by dividing by 1000 (as we had predicted) whilst one pair multiplied by 1000 (Heidi and Ruth, discussed above). Of these, three pairs were able to correct their final calculation in Method B but two pairs were not. The three pairs who solved the problem (all of whom had initially divided by 1000 instead of by $1000^{2}$ ) received teacher intervention at the point of observing the two different sets of answers in the final column of Method A and Method B. The two pairs who were unable to correct their answers did not receive any teacher intervention at this point.

Intervention was typically in the form of the teacher/researcher prompting the students to notice 'how big' the difference was between the numbers. The successful student pairs were then able to see that Method B's answers for ' $x$-sectional area (m2)' were too large by a magnitude of 1000 (see Figure 7).

\begin{tabular}{|c|c|c|c|c|}
\hline & $\begin{array}{l}\text { A } \\
\text { Method A }\end{array}$ & B & C & $D$ \\
\hline 1 & diameter $(\mathrm{mm})$ & radius $(\mathrm{mm})$ & radius $(m)$ & $x$-sectional area $\left(m^{2}\right)$ \\
\hline 2 & 0.27 & 0.135 & 0.000135 & $5.72447 \mathrm{E}-08$ \\
\hline 3 & 1.106 & 0.553 & 0.000553 & $9.60546 \mathrm{E}-07$ \\
\hline$\overline{4}$ & $7.00 \mathrm{E}-02$ & 0.035 & 0.000035 & $3.84773 \mathrm{E}-09$ \\
\hline 5 & $8.30 \mathrm{E}-01$ & 0.415 & 0.000415 & $5.40959 \mathrm{E}-07$ \\
\hline 6 & 13.45 & 6.725 & 0.006725 & 0.000142054 \\
\hline 9 & $\begin{array}{l}\text { Method B } \\
\text { diameter }(\mathrm{mm})\end{array}$ & Radius (mm) & $x$-sectional area $\mathrm{mm}^{2}$ ) & $x$-sectional area $\left(m^{2}\right)$ \\
\hline 10 & 0.27 & 0.135 & 0.057244725 & $5.72447 \mathrm{E}-05$ \\
\hline 11 & 1.106 & 0.553 & 0.960546069 & $9.60546 \mathrm{E}-04$ \\
\hline 12 & $7.00 \mathrm{E}-02$ & 0.035 & 0.003847725 & $3.84773 \mathrm{E}-06$ \\
\hline 13 & $8.30 \mathrm{E}-01$ & 0.415 & 0.540958725 & $5.40959 \mathrm{E}=04$ \\
\hline$\overline{14}$ & 13.45 & 6.725 & $142.053688 \mid$ & 0.142054 \\
\hline
\end{tabular}

Figure 7: Values of cross-sectional area which are correct for method A and incorrect for Method B. Note how Method B's values for cross-sectional area are too small by a magnitude of a 1000 due to dividing by 1000 rather than $1000^{2}$. 


\section{Response Category 2, problem-solving scenario not established}

Students in this category made errors in both Method A and in the final step of Method B. This meant that the values obtained for ' $\mathrm{x}$-sectional area $\left(\mathrm{m}^{2}\right)$ ' in the final column were incorrect in both cases. The confrontation we had intended was therefore not established because although students were left to compare two sets of different values for ' $x$-sectional area $\left(\mathrm{m}^{2}\right)^{\prime}$, both sets were incorrect. Thus it was not possible to intervene in the same way as for those students in Reponse category 1. None of the three pairs (six students) of students who fell into this category successfully completed the task.

Response Category 3, problem-solving scenario redundant

Only one pair of students, Monica and Bev, fell into this category by completing all the conversion steps in Method A and Method B correctly. These two students were able to utilize prior knowledge and use the correct conversion factor of $\div 1000^{2}$ in the final step of Method B without teacher intervention or recourse to Method A's correct values for ' $\mathrm{x}$ sectional area $\left(\mathrm{m}^{2}\right)^{\prime}$.

\section{Discussion}

It seems that where the problem-solving situation was established as we had intended (Response Category 1), the spreadsheet-based task supported the students in learning a previously unknown general rule but required researcher intervention in addition to spreadsheet feedback. Thus, although the correct values for cross-sectional area $\left(\mathrm{m}^{2}\right)$ in Method A served as the auxiliary stimulus necessary to solve the final step of Method B (in accordance with Vygotsky's functional method of double stimulation) the students were not able to respond to this additional stimulus without assistance from a more knowledgeable other.

Out of nine pairs of students, six pairs were aware of the general rule to convert from millimetres to metres; one pair (Heidi and Ruth) possessed the common sense knowledge to 'discover' the general rule anew, and two pairs did not have access to sufficient resources (computer or otherwise) to construct it for themselves.

Vygotsky (1978) proposed that in any domain each child has an 'actual developmental level' (determined by the individual problem-solving) and an immediate potential for development (determined by the problem-solving process under guidance). In some sense, the distance between the two levels is the 'zone of proximal development'. The extent to which individuals are able to use auxiliary stimuli as a 'sign' pointing to a problem's solution can act as an indicator of their 'zone of proximal development'. We designed the spreadsheet activities based on an analysis of classroom observations, written test data and students' interviews in an attempt to ensure we were starting from the perspective of the students. Our analysis suggests that the activity we had designed was within the zone of proximal development of only six pairs of students - the five pairs belonging to Response Category 1 and the single pair belonging to Response Category 3. The task's design was, however, outside the zone of proximal development of the six students in Response Category 2, who knew few general rules and could not resort to alternative strategies to construct appropriate ones.

\section{Conclusions}

In line with the GNVQ philosophy of independent learning, the spreadsheet tasks were designed with the intention that students would learn mathematical ideas essential to 
science. Our premiss was that students would work with minimal intervention from a teacher. However through the analysis presented here, we have become aware of the difficulties faced by these science students when attempting to solve mathematical problems. We were overly reliant on student discussion, computer feedback and the nature of the activities themselves. The case of Heidi and Ruth illustrates how inefficient student strategies can be during independent work supported by too little background knowledge; students must work much harder if they have not formalized common operational procedures. We still conjecture that an appropriately designed spreadsheet conversion activity, which allowed for more teacher direction and emphasis on a general method for converting between units, could offer students a basis for developing an understanding of the power of the general conversion relationship.

The results of this study are beginning to suggest that the practice of teaching key skills within the vocational context is not likely to redress the generally weak understanding of mathematics demonstrated by vocational sience students. We feel that, although independent learning is a central tenet of the new vocational award, it does, in fact, contribute to the difficulties reported (NCVQ, 1995) in teaching and assessing key skills in an effective way. Our findings which suggest that students need guidance from a teacher when working within their zone of proximal development support this view. It is also inevitable, as we have found, that some vocational science students with insufficient background knowledge will be working well outside their zones of proximal development in the mathematical aspects of their course. These students, in particular, are likely to have great difficulties grasping mathematical principles through independent learning in the vocational context.

It is evident that a way has to be found to empower vocational science students with more efficient mathematical strategies in order that they are not disadvantaged in the future in higher education or in the workplace. We have seen that students actively think through problems and seek solutions for themselves, endlessly making sense of their actions. The evidence of Heidi and.Ruth suggests that students do work hard to produce a calculation which fits with their intuitive sense of what is sensible in a science situation. However, on their own they do not always have the resources to sort out the discrepancy between what they produce themselves and what they sense that a calculation should actually look like. Here a teacher is absolutely crucial, otherwise students like Heidi and Ruth are unlikely to develop the mathematical knowledge which that very much need for their work in science.

\section{Acknowledgements}

We want to acknowledge the Leverhulme Trust for funding the research project 'Mathematics for GNVQ Science Students: The Role of Computers'. Thanks are also due to members of the Centre for Learning, Knowing and Interactive Technologies at the University of Bristol, for their support and discussions, and to staff and students at the college in which we worked.

\section{References}

Bruner, J. S. (1957), 'Going beyond the information given', in J. M. Anglin (ed.), Beyond the Information Given (1974), London: George Allen and Unwin, 218-38. 
Dearing, R. (1996), Review of Qualifications for 16-19 Year Olds, London: SCAA.

Department for Education/Employment Department/Welsh Office (1991), Education and Training for the 21st Century, London: HMSO.

Further Education Funding Council (1994), General National Vocational Qualifications in the Further Education Sector in England National Survey Report, Coventry: FEFC.

Further Education Unit, Institute of Education and Nuffield Foundation (1994), GNVQs 1993-94: A National Survey Report; An Interim Report of a Joint Project - The Evolution of GNVQs: Enrolment and Delivery Patterns and their Policy Implications, London: FEU.

Green, A. and Steedman, H. (1993), Education Provision, Education Attainment and the Needs of Industry: A Review of the Research for Germany, France, Japan, the USA and Britain, National Institute of Economic Research, Report No. 5, London: NIESR.

Hodgson, A. and Spours, K. (1997), 'From the 1991 White Paper to the Dearing Report: a conceptual and historical framework for the 1990s', in A. Hodgson and K. Spours (eds.), Dearing and Beyond: 14-19 Qualifications, Frameworks and Systems, London: Kogan Page, 4-24.

Molyneux, S. and Sutherland, R. (1996), 'Mathematical competencies of GNVQ science students: the role of computers. Report to the Leverhulme Trust, September', The University of Bristol, School of Education.

National Council for Vocational Qualifications (1995), GNVQ Assessment Review. Final Report of the Review Group Chaired by Dr John Capey, London: NCVQ.

OFSTED (1994), GNVQs in Schools 1993/4: Quality and Standards of General National Vocational Qualifications, London: HMSO.

Robinson, P. (1996), 'Rhetoric and reality: Britain's new vocational qualifications', special report, The Centre for Economic Performance, London School of Economics, London.

Spours, K. (1997), 'GNVQs and the future of broad vocational qualifications', in A. Hodgson and K. Spours (eds.), Dearing and Beyond: 14-19 Qualifications, Frameworks and Systems, London: Kogan Page, 57-74.

Vygotsky, L. S. (1978), 'Mind in society: the development of higher psychological processes', in C. Cole, V. John-Steiner, S. Scribner and E. Souberman (eds.), Cambridge, Mass.: Harvard University Press.

Wolf, A. (1995), 'Awards that pay lip service to flexibility', Times Education Supplement, London, 6 September 1995. 